PUBLICIANA : JURNAL ILMU SOSIAL DAN ILMU POLITIK

VOLUME 14, NO 02

ISSN : $1979-0295$ / E-ISSN : $2502-7336$

\title{
EVALUASI KEPUASAN MASYARAKAT TERHADAP PELAYANAN PUBLIK DI KANTOR DESA TANGGARAN KECAMATAN PULE KABUPATEN TRENGGALEK
}

\author{
EVALUATION OF COMMUNITY SATISFACTION WITH PUBLIC \\ SERVICES AT THE OFFICE OF TANGGARAN VILLAGE, PULE DISTRICT, \\ TRENGGALEK REGENCY
}

\author{
Slamet Hariyanto ${ }^{1}$, Heru Dwi Susilo \\ ${ }^{1}$ Fakultas Ilmu Sosial dan Ilmu Politik Universitas Tulungagung, Tulungagung, Indonesia. \\ ${ }^{2}$ Fakultas Ilmu Sosial dan Ilmu Politik Universitas Tulungagung, Tulungagung, Indonesia. \\ slamethariyanto@gmail.com \\ herudwisusilo@gmail.com
}

\begin{abstract}
ABSTRAK
Sebagai instansi pelayanan public bagi masyarakat umum, Kantor Desa Tanggaran dituntut untuk memberikan pelayanan yang sesuai dengan harapan masyarakat. Oleh karena itu pihak Kantor Desa harus menjaga kepercayaan dan kepuasan masyarakat dengan meningkatkan kualitas pelayanannya. Tujuan penelitian ini adalah Untuk mengetahui dan menganalisis tingkat kepuasan masyarakat terhadap pelayanan administratif di Kantor Desa Tanggara serta mengetahui factor-faktor pendukung dan penghambat kepuasan masyarakat terhadap pelayanan public di Kantor Desa Tanggaran Kecamatan pule Kabupaten Trenggalek.

Metode penelitian yang digunakan dalam penelitian ini adalah deskriptif dengan analisa kualitatif, lokasi penelitian ini di Kantor Desa Tanggaran Kecamatan Pule Kabupaten Trenggalek. Data primer pada penelitian ini berupa hasil pengisian angket online maupun wawancara kepada masyarakat yang mendapatkan pelayanan publik di Kantor Desa Tanggaran Kecamatan Pule Kabupaten Trenggalek. Data sekunder berupa laporan-laporan, buku-buku, atau catatan-catatan yang berkaitan erat dengan penelitian. Teknik pengumpulan data yang digunakan dalam penelitian ini adalah kuesioner online, wawancara, dan dokumentasi.

Kata Kunci : Kualitas Pelayanan, Kepuasan Masyarakat, Pelayanan Publik, Desa Tanggaran Kecamatan Pule Kabupaten Trenggalek

\section{ABSTRACT}

As a public service agency for the general public, Desa Tanggaran Office is required to provide services that are in accordance with community expectations. Therefore, the Village Office must maintain the trust and satisfaction of the community by improving the quality of its services. The purpose of this study was to determine and analyze the level of community satisfaction with administrative services at the Desa Tanggaran Office and to determine the
\end{abstract}




\section{Slamet Hariyanto ${ }^{1}$, Heru Dwi Susilo ${ }^{2}$}

Evaluasi Kepuasan Masyarakat Terhadap Pelayanan Publik Di Kantor Desa Tanggaran Kecamatan Pule Kabupaten Trenggalek

supporting and inhibiting factors of community satisfaction with public services at the Desa Tanggaran Office, Kecamatan Pule, Kabupaten Trenggalek.

The research method used in this research is descriptive with qualitative analysis, the location of this research is at the Desa Tanggaran Office, Kecamatan Pule, Kabupaten Trenggalek. The primary data in this study were the results of filling out online questionnaires and interviews with people who received public services at the Desa Tanggaran Office, Kecamatan Pule, Kabupaten Trenggalek. Secondary data in the form of reports, books, or notes that are closely related to research. Data collection techniques used in this study were online questionnaires, interviews, and documentation.

Keywords: Service Quality, Community Satisfaction, Public Service, Desa Tanggaran Kecamatan Pule Kabupaten Trenggalek

\section{PENDAHULUAN}

Dalam Manajemen Kinerja sector Publik kualitas pelayanan dipengaruhi antara lain: kecepatan pelayanan; kebersihan, kerapian staf, dan fasilitas; Keramahan dan kesabaran staf dalam melayani; staf yang membantu dan bersahabat serta perhatian pada pelanggan; dan keamanan dan kenyamanan. Sedangkan dalam menentukan indicator kinerja sector public perlu mempertimbangkan indicator biaya (cost of service), dan tingkat utilisasi (utilization rate) yang sifatnya kuantitatif, juga ada mencakup indicator yang sifatnya kualitatif seperti indicator kualitas pelayanan dan standar pelayanan (quality and standards), yang meliputi kecepatan pelayanan, ketepatan waktu, kecepatan respon, keramahan, kenyamanan, kebersihan, keamanan, keindahan (estetika), etika, dan sebagainya. Secara garis besar indicator kualitas pelayanan terdiri antara lain: reliability (keandalan), responsibility (kemampuan merespon), assurance, empathy (perhatian), tangibles (berwujud), credibility (kejujuran), competence (pengetahuan dan ketrampilan), access (kemudahan hubungan), courtesy (perilaku), security (keamanan) dan lain sebagainya.

Pemerintah mempunyai peranan penting dalam menyediakan layanan publik sesuai yang telah diamanatkan dalam Undang-Undang Nomor 25 Tahun 2009 tentang pelayanan publik pasal 1 menyebutkan bahwa : "Pelayanan Publik adalah kegiatan atau rangkaian kegiatan dalam rangka pemenuhan kebutuhan pelayanan sesuai dengan peraturan perundang-undangan bagi setiap warga negara dan penduduk atas barang, jasa dan / atau pelayanan administrative yang disediakan oleh penyelenggara pelayanan publik". Sementara itu di dalam Undang-Undang Nomor 23 Tahun 2014 tentang Pemerintahan Daerah menjelaskan bahwa "penyelenggaraan pemerintahan daerah diarahkan untuk mempercepat terwujudnya kesejahteraan masyarakat melalui peningkatan pelayanan, pemberdayaan, dan peran serta masyarakat". Kualitas pelayanan merupakan suatu kondisi dimana terciptanya hubungan yang dinamis antara pengguna layanan maupun pemberi layanan. Apabila layanan yang diberikan sudah sesuai dengan yang diharapkan oleh pengguna layanan, maka pelayanan tersebut merupakan pelayanan yang berkualitas. Sebaliknya jika layanan yang diberikan tidak sesuai dengan yang diharapkan pengguna layanan, maka pelayanan tersebut tidak berkualitas. Baik buruknya kualitas layanan bukan berdasarkan sudut pandang atau persepsi penyedia jasa atau layanan melainkan berdasarkan pada persepsi konsumen dan aturan atau ketentuan yang berlaku tentang kualitas pelayanan.

Rendahnya mutu pelayanan publik yang diberikan oleh aparatur pemerintah menjadi citra

buruk pemerintah di dalam masyarakat. Sebagian masyarakat yang pernah berurusan dengan 


\section{PUBLICIANA : JURNAL ILMU SOSIAL DAN ILMU POLITIK \\ VOLUME 14 NO 2 \\ ISSN : 1979 - 0295 / E-ISSN : $2502-7336$}

birokrasi selalu mengeluh dan kecewa terhadap berbagai pelayanan yang diberikan. Bahkan ada sebagian masyarakat yang sampai saat ini masih menganggap rendah terhadap kinerja birokrasi. Pelayanan yang diberikan secara umum belum memuaskan masyarakat. Pelayanan yang diberikan terlalu berbelit-belit dengan memberikan berbagai alasan yang tidak dapat diterima oleh masyarakat, sehingga pelayanan yang diberikan cenderung tidak efektif dan efisien. Keadaan yang demikian membuat masyarakat sebagai pengguna layanan publik tidak terpuaskan dengan pelayanan yang diberikan. Hal tersebut mengakibatkan masyarakat enggan mengurus segala sesuatu yang berhubungan dengan birokrasi pemerintah secara langsung.

Dalam melaksanakan kinerja, pihak pemerintah Desa harus terlebih dahulu melihat semua faktor kemungkinan yang ada,baik itu kesempatan,peluang atau tantangan serta hambatan yang ada dalam era otonomi ini serta penyelenggaraan pemerintah haruslah pula menjawab serta memenuhi kehendak pelanggan yaitu masyarakat di Desa yang memerlukan pelayanan secara optimal agar tercipta suatu keadaan yang menggambarkan good governance di Kantor Desa. Kegiatan pelayanan yang diberikan Kantor Desa Tanggaran akan dinilai dari tingkat kepuasan masyarakat. Penilaian yang diberikan masyarakat menentukan ukuran kinerja pelayanan publik di Kantor Desa Tanggaran. Untuk mengetahui baik buruknya kualitas pelayanan publik adalah dengan mengukur tingkat kepuasan masyarakat. Berdasarkan pengamatan awal yang telah dilakukan di kantor Desa Tanggaran, terdapat beberapa permasalahan yang dijumpai pada bagian pelayanan . Oleh karena itu, perlu pembenahan dalam standar pelayanan kepada masyarakat untuk meningkatkan kualitas pelayanan publik di Kantor Desa Tanggaran.

\section{KERANGKA TEORI}

\section{A. PELAYANAN PUBLIK}

1. Pengertian Pelayanan Publik

Menurut Kamus Bahasa Indonesia, pelayanan memiliki tiga makna, perihal atau cara melayani; usaha melayani kebutuhan orang lain dengan memperoleh imbalan (uang); kemudahan yang diberikan sehubungan dengan jual beli barang atau jasa. Menurut Lovelock (1991:7), "service adalah produk yang tidak berwujud, berlangsung sebentar dan dirasakan atau dialami." Artinya service merupakan produk yang tidak ada wujud atau bentuknya sehingga tidak ada bentuk yang dapat dimiliki, dan berlangsung sesaat atau tidak tahan lama, tetapi dialami dan dapat dirasakan oleh penerima layanan. Dari uraian tersebut, maka pelayanan dapat diartikan sebagai kegiatan untuk membantu, menyiapkan serta mengurus baik itu berupa barang atau jasa dari satu pihak kepada pihak lain.

Berdasarkan Keputusan Menteri Pendayagunaan Aparatur Negara Nomor 63 Tahun 2003, definisi dari pelayanan umum adalah: Segala bentuk pelayanan yang dilaksanakan oleh instansi pemerintah di pusat, di daerah, dan di lingkungan Badan Usaha Milik Negara atau Badan Usaha Milik Daerah dalam bentuk barang dan atau jasa, baik dalam rangka upaya pemenuhan kebutuhan masyarakat maupun dalam rangka pelaksanaan ketentuan peraturan perundangundangan. Sedangkan berdasarkan Bab I Pasal 1 Ayat 1 UU No. 25/2009, yang dimaksud dengan pelayanan publik adalah kegiatan atau rangkaian kegiatan dalam rangka pemenuhan kebutuhan pelayanan sesuai dengan peraturan perundang-undangan bagi setiap warga negara dan penduduk atas barang, jasa, dan/atau pelayanan administratif yang disediakan oleh penyelenggara pelayanan publik. Dari pengertian dan penjelasan tersebut, terdapat 3 unsur penting dalam pelayanan publik, yaitu: unsur pertama, adalah organisasi pemberi (penyelenggara) pelayanan 


\section{Slamet Hariyanto ${ }^{1}$, Heru Dwi Susilo ${ }^{2}$}

Evaluasi Kepuasan Masyarakat Terhadap Pelayanan Publik Di Kantor Desa Tanggaran Kecamatan Pule Kabupaten Trenggalek

yaitu Pemerintah/ Pemerintah Daerah, unsur kedua, adalah penerima layanan (pelanggan) yaitu orang atau masyarakat atau organisasi yang berkepentingan, dan unsur ketiga, adalah kepuasan yang diberikan dan/atau diterima oleh penerima layanan (pelanggan).

2. Klasifikasi Pelayanan Publik

Pelayanan publik yang harus diberikan oleh pemerintah dapat diklasifikasikan ke dalam dua kategori utama, yaitu: pelayanan kebutuhan dasar dan pelayanan umum. Mahmudi (2005) dalam Hardiyansyah (2018: 20-24) menjelaskannya sebagai berikut:

a. Pelayanan Kebutuhan Dasar

Pelayanan kebutuhan dasar yang harus diberikan oleh pemerintah meliputi: kesehatan, pendidikan dasar, dan bahan kebutuhan pokok masyarakat

1) Kesehatan

Kesehatan merupakan salah satu kebutuhan dasar masyarakat, maka kesehatan adalah hak bagi setiap warga masyarakat yang dilindungi oleh Undang-Undang Dasar. Setiap negara mengakui bahwa kesehatan menjadi modal terbesar untuk mencapai kesejahteraan. Oleh karena itu, perbaikan pelayanan kesehatan pada dasarnya merupakan suatu investasi sumber daya manusia untuk mencapai masyarakat yang sejahtera (welfare society).

2) Pendidikan Dasar

Bentuk pelayanan dasar lainnya adalah pendidikan dasar. Sama hanya dengan kesehatan, pendidikan merupakan suatu bentuk investasi sumber daya manusia. Masa depan suatu bangsa akan sangat ditentukan oleh seberapa besar perhatian pemerintah terhadap pendidikan masyarakatnya. Tingkat pendidikan juga berpengaruh terhadap tingkat kemiskinan karena pendidikan merupakan salah satu komponen utama dalam lingkaran setan kemiskinan sebagaimana digambarkan di atas. Oleh karena itu, untuk memotong lingkaran setan kemiskinan salah satu caranya adalah melalui perbaikan kualitas pendidikan. Pada pemerintahan kita pendidikan dasar diterjemahkan dalam Program Wajib Belajar Sembilan Tahun. Pendidikan dasar tersebut pada dasarnya merupakan kewajiban pemerintah untuk menyelenggarakannya. Idealnya pemerintah mensubsidi penuh pendidikan dasar ini sehingga tidak ada alasan bagi oang tua untuk mampu menyekolahkan anaknya. Pemerintah hendaknya menjamin bahwa semua anak dapat bersekolah. Untuk melakukan hal itu diperlukan anggaran pendidikan yang besar. Dalam pemenuhan anggaran tersebut amanat amandemen UUD 1945 telah mensyaratkan alokasi anggaran pendidikan sebenarnya bukan biaya akan tetapi investasi jangka panjang yang manfaatnya juga bersifat jangka panjang.

3) Bahan Kebutuhan Pokok

Selain kesehatan dan pendidikan, pemerintah juga harus memberikan pelayanan kebutuhan dasar yang lain, yaitu bahan kebutuhan pokok. Bahan kebutuhan pokok masyarakat itu misalnya: beras, minyak goreng, minyak tanah, gula pasir, daging, telur ayam, susu, garam beryodium, tepung terigu, sayur mayur, semen, dan sebagainya. Dalam hal penyediaan bahan kebutuhan pokok, pemerintah perlu menjamin stabilitas harga kebutuhan pokok masyarakat dan menjaga ketersediaannya di pasar maupun di gudang dalam bentuk cadangan atau persediaan. Lonjakan harga kebutuhan pokok masyarakat yang terlalu tinggi akan memberikan dampak negatif bagi perekonomian makro, misalnya memicu terjadi inflasi yang tinggi (hiperinflasi). Selain itu, ketidakstabilan 


\section{PUBLICIANA : JURNAL ILMU SOSIAL DAN ILMU POLITIK \\ VOLUME 14 NO 2 \\ ISSN : 1979 - 0295 / E-ISSN : $2502-7336$}

harga bahan kebutuhan pokok yang tidak terkendali juga dapat menimbulkan ketidakstabilan politik. Selain menjaga stabilitas harga-harga umum, pemerintah juga perlu menjamin bahwa cadangan persediaan di gudang pemerintah cukup untuk memenuhi kebutuhan masyarakat sampai jangka waktu tertentu. Hal ini untuk menghindari terjadinya kepanikan masyarakat terhadap kelangkaan bahan kebutuhan pokok, sehingga tidak terjadi antrian panjang untuk mendapatkan bahan kebutuhan tertentu.

b. Pelayanan Umum

Selain pelayanan kebutuhan dasar, pemerintah sebagai instansi penyedia pelayanan publik juga harus memberikan pelayanan umum kepada masyarakatnya. Pelayanan umum yang harus diberikan pemerintah terbagi dalam tiga kelompok, yaitu: pelayanan administratif, pelayanan barang, dan pelayanan jasa.

1) Pelayanan administrative

Pelayanan administratif adalah pelayanan berupa penyediaan berbagai bentuk dokumen yang dibutuhkan oleh publik, misalnya: Pembuatan Kartu Tanda Penduduk (KTP), Sertifikat Tanah, Akta Kelahiran, Akta Kematian, Buku Pemilik Kendaraan Bermotor (BPKB), Surat Tanda Nomor Kendaraan Bermotor (STNK), Izin Mendirikan Bangunan (IMB), Paspor, dan sebagainya.

2) Pelayanan Barang

Pelayanan barang adalah pelayanan yang menghasilkan berbagai bentuk/jenis barang yang menjadi kebutuhan publik, misalnya: Jaringan telepon, Penyediaan tenaga listrik, Penyediaan air bersih.

3) Pelayanan Jasa

Pelayanan jasa adalah pelayanan yang menghasilkan berbagai bentuk jasa yang dibutuhkan publik, misalnya: Pendidikan tinggi dan menengah, Pemeliharaan kesehatan, Penyelenggaraan transportasi, Jasa pos, Sanitasi lingkungan, Persampahan, Drainase, Jalan dan trotoar, Penanggulangan bencana: banjir, gempa, gunung meletus, dan kebakaran, Pelayanan sosial (asuransi atau jaminan sosial/social security).

\section{Asas-asas Pelayanan Publik}

Pelayanan publik dilakukan untuk memberikan kepuasan bagi pengguna jasa, karena itu penyelenggaraannya membutuhkan asas-asas pelayayanan. Dengan kata lain, dalam memberikan pelayanan publik, instansi penyedia pelayanan publik harus memperhatikan asas pelayanan publik.

Asas-asas pelayanan publik menurut Keputusan Menpan Nomor 63/2003 sebagai berikut:

a. Transparansi. Bersifat terbuka, mudah dan dapat diakses oleh semua pihak yang membutuhkan dan disediakan secara memadai serta mudah dimengerti.

b. Akuntabilitas. Dapat dipertanggungjawabkan sesuai dengan ketentuan peraturan perundang-undangan.

c. Kondisional. Sesuai dengan kondisi dan kemampuan pemberi dan penerima pelayanan dengan tetap berpegang pada prinsip efisiensi dan efektivitas.

d. Partisipatif. Mendorong peran serta masyarakat dalam penyelenggaraan pelayanan publik dengan memperhatikan aspirasi, kebutuhan dan harapan masyarakat. 


\section{Slamet Hariyanto ${ }^{1}$, Heru Dwi Susilo ${ }^{2}$}

Evaluasi Kepuasan Masyarakat Terhadap Pelayanan Publik Di Kantor Desa Tanggaran Kecamatan Pule Kabupaten Trenggalek

e. Kesamaan Hak. Tidak diskriminatif dalam arti tidak membedakan suku, ras, agama, golongan, gender dan status ekonomi.

f. Keseimbangan Hak dan Kewajiban. Pemberi dan penerima pelayanan publik harus memenuhi hak dan kewajiban masingmasing pihak.

Sedangkan menurut Pasal 4 UU No. 25/2009, penyelenggaraan pelayanan publik berasaskan:

a. kepentingan umum

b. kepastian hokum

c. kesamaan hak

d. keseimbangan hak dan kewajiban

e. keprofesionalan

f. partisipatif

g. persamaan perlakuan/tidak diskriminatif

h. keterbukaan

i. akuntabilitas

j. fasilitas dan perlakuan khusus bagi kelompok rentan

k. ketepatan waktu

1. kecepatan, kemudahan, dan keterjangkauan.

4. Penyelenggara Pelayanan Publik

Menurut Pasal 1 Ayat 4 UU No. 25/2009, bahwa penyelenggara pelayanan publik adalah setiap institusi penyelenggara negara, korporasi, lembaga independen yang dibentuk berdasarkan Undang- Undang untuk kegiatan pelayanan publik, dan badan hukum lain yang dibentuk sematamata untuk kegiatan pelayanan publik. Pada Ayat 6 Undang-Undang yang sama disebutkan bahwa pelaksana pelayanan publik adalah pejabat, pegawai, petugas, dan setiap orang yang bekerja di dalam Organisasi Penyelenggara yang bertugas melaksanakan tindakan atau serangkaian tindakan pelayanan public.

5. Prinsip-prinsip Penyelenggaraan Pelayanan Publik

Sepuluh Prinsip pelayanan umum diatur dalam Keputusan Menteri Negara Pemberdayaan Aparatur Negara No. 63/KEP/M.PAN/7/2003 Tentang Pedoman Umum Penyelenggaraan Pelayanan Publik, kesepuluh prinsip tersebut adalah sebagai berikut;

a. Kesederhanaan : Prosedur pelayanan publik tidak berbelitbelit, mudah dipahami, dan mudah dipahami, dan mudah dilaksanakan

b. Kejelasan:

1. Persyaratan teknis dan adminsitratif pelayanan public

2. Unit kerja/pejabat yang berwenang dan bertanggungjawab dalam memberikan pelayanan dan penyelesaian keluhan/persoalan/ sengketa dalam pelaksanaan pelayanan publik

3. Rincian biaya pelayanan publik dan tata cara pembayaran.

c. Kepastian waktu : Pelaksanaan pelayanan publik dapat diselesaikan dalam kurun waktu yang telah ditentukan.

d. Akurasi : Produk pelayanan publik diterima dengan benar, tepat dan sah.

e. Keamanan : Proses dan produk pelayanan publik memberikan rasa aman dan kepastian hukum. 


\section{PUBLICIANA : JURNAL ILMU SOSIAL DAN ILMU POLITIK \\ VOLUME 14 NO 2 \\ ISSN : 1979 - 0295 / E-ISSN : $2502-7336$}

f. Tanggung jawab : Pimpinan penyelenggara pelayanan publik atau pejabat yang ditunjuk bertanggungjawab atas penyelenggaraan pelayanan dan penyelesaian keluhan/persoalan dalam pelaksanaan pelayanan publik.

g. Kelengkapan sarana dan prasarana kerja, peralatan kerja dan pendukung lainnya yang memadai termasuk penyediaan sarana teknologi, telekomunikasi dan informatika (teletematika).

h. h.Kemudahan Akses : Tempat dan lokasi sarana prasarana pelayanan yang memadai, mudah dijangkau oleh masyarakat dan dapat memanfaatkan teknologi telekomunikasi dan informasi.

i. Kedisiplinan, Kesopanan dan Keramahan : Pemberi pelayanan harus bersikap disiplin, sopan dan santun, ramah, serta memberikan pelayanan dengan ikhlas.

j. Kenyamanan : Lingkungan pelayanan harus tertib, teratur, disediakan ruang tunggu yang nyaman, bersih, rapih, lingkungan yang indah dan sehat, serta dilengkapi dengan fasilitas pendukung pelayanan, seperti parkir, toilet, tempat ibadah dan lainnya.

Pasal 34 UU No. 25/2009 disebutkan bahwa pelaksana dalam menyelenggarakan pelayanan publik harus berperilaku sebagai berikut:

a. adil dan tidak diskriminatif

b. cermat

c. santun dan ramah

d. tegas, andal, dan tidak memberikan putusan yang berlarut-larut

e. professional

f. tidak mempersulit

g. patuh pada perintah atasan yang sah dan wajar

h. menjunjung tinggi nilai-nilai akuntabilitas dan integritas institusi penyelenggara

i. tidak membocorkan informasi atau dokumen yang wajib dirahasiakan sesuai dengan peraturan perundang-undangan

b. terbuka dan mengambil langkah yang tepat untuk menghindari benturan kepentingan

c. tidak menyalahgunakan sarana dan prasarana serta fasilitas pelayanan public

d. tidak memberikan informasi yang salah atau menyesatkan dalam menanggapi permintaan informasi serta proaktif dalam memenuhi kepentingan masyarakat

e. tidak menyalahgunakan informasi, jabatan, dan/atau kewenangan yang dimiliki

f. sesuai dengan kepantasan

g. tidak menyimpang dari prosedur.

6. Standar Pelayanan Publik

Setiap Penyelenggaraan pelayanan publik harus memiliki standar pelayanan, sebagai jaminan adanya kepastian bagi pemberi didalam pelaksanaan tugas dan fungsinya dan bagi penerima pelayanan dalam proses pengajuan permohonannya. Standar pelayanan merupakan ukuran yang dibakukan dalam penyelenggaraan pelayanan public sebagai pedoman yang wajib ditaati dan dilaksanakan oleh penyelenggara pelayanan, dan menjadi pedoman bagi penerima pelayanan dalam proses pengajuan permohonan, serta sebagai alat control masyarakat dan/atau penerima layanan atas kinerja penyelenggara pelayanan. 


\section{Slamet Hariyanto ${ }^{1}$, Heru Dwi Susilo ${ }^{2}$}

Evaluasi Kepuasan Masyarakat Terhadap Pelayanan Publik Di Kantor Desa Tanggaran Kecamatan Pule Kabupaten Trenggalek

Oleh karena itu perlu disusun dan ditetapkan standar pelayanan sesuai dengan sifat, jenis dan karakteristik layanan yang diselenggarakan, serta memperhatikan kebutuhan dan kondisi lingkungan. Dalam proses perumusan dan penyusunannya melibatkan masyarakat dan/atau stakeholder lainnya (termasuk aparat birokrasi) untuk mendapatkan saran dan masukan, membangun kepedulian dan komitmen meningkatkan kualitas pelayanan.

Standar Pelayanan Publik menurut PERMENPAN No.14 Tahun 2017 meliputi sebagai berikut :

1. Persyaratan

Persyaratan adalah syarat yang harus dipenuhi dalam pengurusan suatu jenis pelayanan, baik persyaratan teknis maupun administratif.

2. Sistem, Mekanisme, dan Prosedur

Prosedur adalah tata cara pelayanan yang dibakukan bagi pemberi dan penerima pelayanan, termasuk pengaduan.

3. Waktu Penyelesaian

Waktu Penyelesaian adalah jangka waktu yang diperlukan untuk menyelesaikan seluruh proses pelayanan dari setiap jenis pelayanan.

4. Biaya/Tarif

Biaya/Tarif adalah ongkos yang dikenakan kepada penerima layanan dalam mengurus dan/atau memperoleh pelayanan dari penyelenggara yang besarnya ditetapkan berdasarkan kesepakatan antara penyelenggara dan masyarakat.

5. Produk Spesifikasi Jenis Pelayanan

Produk spesifikasi jenis pelayanan adalah hasil pelayanan yang diberikan dan diterima sesuai dengan ketentuan yang telah ditetapkan. Produk pelayanan ini merupakan hasil dari setiap spesifikasi jenis pelayanan.

6. Kompetensi Pelaksana

Kompetensi Pelaksana adalah kemampuan yang harus dimiliki oleh pelaksana meliputi pengetahuan, keahlian, keterampilan, dan pengalaman.

7. Perilaku Pelaksana

Perilaku Pelaksana adalah sikap petugas dalam memberikan pelayanan.

8. Penanganan Pengaduan, Saran dan Masukan

Penanganan pengaduan, saran dan masukan, adalah tata cara pelaksanaan penanganan pengaduan dan tindak lanjut.

9. Sarana dan Prasarana

Sarana adalah segala sesuatu yang dapat dipakai sebagai alat dalam mencapai maksud dan tujuan. Prasarana adalah segala sesuatu yang merupakan penunjang utama terselenggaranya suatu proses (usaha, pembangunan, proyek). Sarana digunakan untuk benda yang bergerak (komputer, mesin) dan prasarana untuk benda yang tidak bergerak (gedung).

Penyusunan standar pelayanan publik harus disusun dengan baik dan tidak rumit, untuk itu harus mempertimbangkan aspek; kemampuan, kelembagaan dan aparat penyelenggara pelayanan, serta potensi daerah dan karakteristik social budaya masyarakat setempat. Dengan demikian, standar pelayanan publik yang ditetapkan dapat dilaksanakan dengan baik, terutama oleh para pelaksana operasional pelayanan yang berhadapan langsung dengan masyarakat, serta mudah dimengerti dan diterima oleh masyarakat/stakeholder. 


\section{PUBLICIANA : JURNAL ILMU SOSIAL DAN ILMU POLITIK \\ VOLUME 14 NO 2 \\ ISSN : 1979 - 0295 / E-ISSN : $2502-7336$}

\section{B. KUALITAS PELAYANAN PUBLIK}

1. Pengertian Kualitas Pelayanan Publik

Kata "kualitas" mengandung banyak pengertian, menurut Kamus Bahasa Indonesia, kualitas berarti: (1) tingkat baik buruknya sesuatu; (2) derajat atau taraf (kepandaian, kecakapan, dsb); atau mutu. Pengertian kualitas menurut (Tjiptono, 2004) adalah: Kesesuaian dengan persyaratan, Kecocokan untuk pemakaian Perbaikan berkelanjutan, Bebas dari kerusakan/cacat, Pemenuhan kebutuhan pelangggan sejak awal dan setiap saat, Melakukan segala sesuatu secara benar, Sesuatu yang bisa membahagiakan pelanggan. Menurut Ibrahim (2008:22), kualitas pelayanan publik merupakan suatu kondisi dinamis yang berhubungan dengan produk, jasa, manusia, proses dan lingkungan dimana penilaian kualitasnya ditentukan pada saat terjadinya pemberian pelayanan publik tersebut. Pada prinsipnya pengertian-pengertian tersebut diatas dapat diterima. Yang menjadi pertanyaan adalah ciri-ciri atau atribut-atribut apakah yang ikut menentukan kualitas pelayanan publik tersebut. Ciri- ciri atau atribut-atribut tersebut antara lain adalah: "(1) Ketepatan waktu pelayanan, yang meliputi waktu tunggu dan waktu proses. (2) Akurasi pelayanan, yang meliputi bebas dari kesalahan. (3) Kesopanan dan keramahan dalam memberikan pelayanan. (4) Kemudahan mendapatkan pelayanan, misalnya banyaknya petugas yang melayani dan banyaknya fasilitas pendukung seperti computer. (5) Kenyamanan dalam memperoleh pelayanan, berkaitan dengan lokasi, ruang tempat pelayanan, tempat parkir, ketersediaan informasi dan lain-lain. (6) Atribut pendukung pelayanan lainnya seperti ruang tunggu ber-AC, kebersihan dan lain-lain". (Tjiptono 1995:25)

Menurut Instruksi Presiden Nomor 1 Tahun 1995 tentang Perbaikan dan Peningkatan Mutu Pelayanan, dinyatakan bahwa hakekat pelayanan umum adalah:

a. Meningkatkan mutu produktivitas palaksanaan tugas dan fungsi instansi pemerintah di bidang pelayanan umum.

b. Mendorong upaya mengefektifkan sistem dan tata laksana pelayanan, sehingga pelayanan umum dapat diselenggarakan secara berdaya guna dan berhasil guna.

c. Mendorong tumbuhnya kreativitas, prakarsa dan peran serta masyarakat dalam pembangunan serta dengan meningkatkan kesejahteraan masyarakat luas.

Oleh karena itu dalam pelayanan publik harus mengandung unsur unsur dasar sebagai berikut:

a. Hak dan kewajiban bagi pemberi maupun pelayanan umum harus jelas dan diketahui secara pasti oleh masing-masing pihak

b. Pengaturan setiap bentuk pelayanan umum harus disesuaikan dengan kondisi kebutuhan dan kemampuan masyarakat untuk membayar berdasarkan ketentuan perundangundangan yang berlaku dengan tetap berpegang teguh pada efisiensi dan efektivitas

c. Kualitas, proses dan hasil pelayanan umum harus diupayakan agar dapat memberi keamanan, kenyamanan, kepastian hukum yang dapat dipertanggungjawabkan "Terciptanya kepuasan pelanggan dapat memberikan berbagai manfaat, diantaranya hubungan antara pelanggan dan pemberi layanan menjadi harmonis, sehingga memberikan dasar yang baik bagi terciptanya loyalitas pelanggan, membentuk suatu rekomendasi dari mulut ke mulut (word of mouth) yang menguntungkan bagi pemberi layanan, reputasi yang semakin baik di mata pelanggan, serta laba (PAD) yang diperoleh akan semakin meningkat". (Tjiptono, 1995:42).

\section{KEPUASAN MASYARAKAT}




\section{Slamet Hariyanto ${ }^{1}$, Heru Dwi Susilo ${ }^{2}$}

Evaluasi Kepuasan Masyarakat Terhadap Pelayanan Publik Di Kantor Desa Tanggaran Kecamatan Pule Kabupaten Trenggalek

\section{Pengertian Kepuasan Masyarakat}

Kata "kepuasan" atau satisfaction berasal dari bahasa latin "satis" (artinya cukup baik, memadai) dan "facio" (melakukan atau membuat), sehingga secara sederhana dapat diartikan sebagai upaya memenuhi sesuatu (Tjiptono, 2000:89). "Kepuasan pelanggan merupakan tingkat kepuasan seseorang setelah membandingkan kinerja atau hasil yang dirasakannya dengan harapannya. Jadi, tingkat kepuasan merupakan fungsi dari perbedaan antara kinerja yang dirasakan dengan harapan. Apabila kinerja dibawah harapan, maka pelanggan akan kecewa. Apabila kinerja sesuai dengan harapan, pelanggan akan puas". (Oliver dalam Supranto. 1997:233). Kepuasan pelanggan adalah hasil pendapat dan penilaian masyarakat terhadap kinerja pelayanan yang diberikan oleh aparatur penyelenggara pelayanan publik (Kepmen PAN No. 25 tahun 2004). Menurut Rangkuti kepuasan pelanggan didefinisikan sebagai respon pelanggan terhadap ketidak sesuaian antara tingkat kepentingan sebelumnya dan kinerja actual yang dirasakan setelah pemakaian. Salah satu konsep dasar dalam memuaskan pelanggan minimal mengacu pada:

a. Keistimewaan yang terdiri dari sejumlah keistimewaan produk, baik keistimewaan langsung maupun keistimewaan atraktif yang dapat memenuhi keinginan pelanggan dan dengan demikian dapat memberikan kepuasan dalam menggunakan produk itu.

b. Kualitas terdiri dari segala sesuatu yang bebas dari kekurangan atau kerusakan.

Berdasarkan pengertian kepuasan pelanggan (masyarakat) di atas, maka dapat disimpulkan bahwa kepuasan pelanggan (masyarakat) merupakan respon dan pendapat seseorang yang berupa perasaan puas atau tidak puas, senang atau kecewa terhadap kinerja pelayanan yang diberikan oleh aparatur penyelenggara pelayanan publik dibandingkan dengan harapannya.

\section{Indeks Kepuasan Masyarakat}

Tujuan utama penyedia jasa adalah memberikan kepuasan kepada pelanggannya, meskipun demikian, tidaklah mudah untuk mewujudkan kepuasan pelanggan secara menyeluruh. Apalagi pelanggan yang dihadapi penyedia jasa pada saat ini adalah pelanggan yang semakin terdidik dan menyadari akan hak-haknya. Oleh karena itu walaupun tidak mudah untuk mewujudkan kepuasan pelanggan secara total, tentu saja penyedia jasa harus berusaha meminimalkan ketidakpuasan pelanggan. Salah satu usaha yang dapat dilakukan oleh penyedia jasa untuk meminimalkan ketidakpuasan pelanggan adalah dengan cara mengadakan pengukuran terhadap indeks kepuasan pengguna jasa (masyarakat) yang dapat dijadikan pedoman bagi penyedia jasa untuk melakukan perbaikan-perbaikan pelayanan sesuai dengan harapan dan kebutuhan masyarakat. Indeks kepuasan masyarakat adalah data dan informasi tentang tingkat kepuasan masyarakat yang diperoleh dari hasil pengukutan secara kuantitatif dan kualitatif atas pendapat masyarakat dalam memperoleh pelayanan dari aparatur penyelenggara pelayanan publik dengan membandingkan antara harapan dan kebutuhannya (Kepmen PAN No. 25 tahun 2004).

\section{Indicator Kepuasan Masyarakat}

Indikator Kepuasan Masyarakat yang akan dijadikan instrument pengukuran berdasarkan PERMENPAN No. 14 Tahun 2017 meliputi 9 indikator untuk melakukan pengukuran atas indeks kepuasan masyarakat akan pelayanan publik adalah sebagai berikut :

\section{Persyaratan}

Persyaratan adalah syarat yang harus dipenuhi dalam pengurusan suatu jenis pelayanan, baik persyaratan teknis maupun administratif. 


\section{PUBLICIANA : JURNAL ILMU SOSIAL DAN ILMU POLITIK \\ VOLUME 14 NO 2 \\ ISSN : 1979 - 0295 / E-ISSN : 2502 - 7336}

2. Sistem, Mekanisme, dan Prosedur

Prosedur adalah tata cara pelayanan yang dibakukan bagi pemberi dan penerima pelayanan, termasuk pengaduan.

3. Waktu Penyelesaian

Waktu Penyelesaian adalah jangka waktu yang diperlukan untuk menyelesaikan seluruh proses pelayanan dari setiap jenis pelayanan.

4. Biaya/Tarif

Biaya/Tarif adalah ongkos yang dikenakan kepada penerima layanan dalam mengurus dan/atau memperoleh pelayanan dari penyelenggara yang besarnya ditetapkan berdasarkan kesepakatan antara penyelenggara dan masyarakat.

5. Produk Spesifikasi Jenis Pelayanan

Produk spesifikasi jenis pelayanan adalah hasil pelayanan yang diberikan dan diterima sesuai dengan ketentuan yang telah ditetapkan. Produk pelayanan ini merupakan hasil dari setiap spesifikasi jenis pelayanan.

6. Kompetensi Pelaksana

Kompetensi Pelaksana adalah kemampuan yang harus dimiliki oleh pelaksana meliputi pengetahuan, keahlian, keterampilan, dan pengalaman.

7. Perilaku Pelaksana

Perilaku Pelaksana adalah sikap petugas dalam memberikan pelayanan.

8. Penanganan Pengaduan, Saran dan Masukan

Penanganan pengaduan, saran dan masukan, adalah tata cara pelaksanaan penanganan pengaduan dan tindak lanjut.

9. Sarana dan Prasarana

Sarana adalah segala sesuatu yang dapat dipakai sebagai alat dalam mencapai maksud dan tujuan. Prasarana adalah segala sesuatu yang merupakan penunjang utama terselenggaranya suatu proses (usaha, pembangunan, proyek). Sarana digunakan untuk benda yang bergerak (komputer, mesin) dan prasarana untuk benda yang tidak bergerak (gedung).

\section{Pengukuran Kepuasan}

Biasanya penyelenggara pelayanan publik melakukan beberapa pengukuran pada tingkat kepuasan masyarakat yang bertujuan untuk mengetahui kinerja dari pelayanan publik. Menurut Kotler (Nasution, 2005:66) ada empat metode untuk mengukur kepuasan pelanggan, yaitu:

a. Sistem keluhan dan sasaran

Setiap organisasi yang berorientasi pada pelanggan perlu memberikan kesempatan yang luas kepada para pelanggannya untuk menyampaikan saran, pendapat, dan keluhan mereka. media yang digunakan bisa berupa kotak saran yang diletakkan ditempat yang strategis, kartu komentar, saluran telepon khusus bebas pulsa, dan lain-lain.

b. Ghost shopping

Ghost shopping adalah metode pengukuran kepuasan pelanggan dengan cara mempekerjakan beberapa orang untuk berperan atau bersikap sebagai pelanggan. Ghost shopper adalah pekerja/pegawai perusahaan yang ditujuk untuk berperan atau berpura-pura sebagai pelanggan perusahaan, baik di perusahaan yang bersangkutan maupun di perusahaan pesaing. Kemudian ghost shopper melaporkan berbagai temuan penting berdasarkan pengalamannya mengenai kekuatan dan kelemahan jasa perusahaan dibandingkan para pesaing. Selain itu ghost 


\section{Slamet Hariyanto ${ }^{1}$, Heru Dwi Susilo ${ }^{2}$}

Evaluasi Kepuasan Masyarakat Terhadap Pelayanan Publik Di Kantor Desa Tanggaran Kecamatan Pule Kabupaten Trenggalek

shopper juga dapat mengamati cara perusahaan dan pesaingnya dalam melayani permintaan pelanggan, menjawab pertanyaan pelanggan dan menangani setiap keluhan.

c. Analisa Kehilangan Pelanggan

Analisa Kehilangan Pelanggan (Lost customer analysis) adalah metode pengukuran kepuasan pelanggan dengan cara menghubungi pelanggan yang telah berhenti menggunakan produk atau yang telah beralih ke pemasok lain. Perusahaan seyogyanya menghubungi para pelanggan yang telah berhenti membeli atau yang telah pindah pemasok agar dapat memahami mengapa hal itu terjadi dan upaya dapat mengambil kebijakan perbaikan/penyempurnaan selanjutnya.

d. Survei kepuasan pelanggan

Umumnya banyak penelitian mengenai kepuasan pelanggan yang dilakukan dengan penelitian survei, baik dengan survei melalui pos, telepon, maupun wawancara pribadi. Metode survei merupakan metode yang paling banyak digunakan dalam pengukuran kepuasan pelanggan. Metode survei kepuasan pelanggan dapat menggunakan pengukuran dengan berbagai cara sebagai berikut:

1) Pengukuran dapat dilakukan secara langsung dengan pertanyaan seperti " Ungkapan seberapa puas Saudara terhadap pelayanan di Administratif di Desa Tanggaran Kecamatan Pule Kabupaten Trenggalek pada skala berikut: sangat tidak puas, tidak puas, netral, puas, sangat puas" (directly reported satisfaction).

2) Responden diberi pertanyaan mengenai seberapa besar mereka mengharapkan suatu atribut tertentu dan seberapa besar yang mereka rasakan (derived dissatisfaction).

3) Responden diminta untuk menuliskan masalah-masalah yang mereka hadapi berkaitan dengan penawaran dari perusahaan dan juga diminta untuk menuliskan perbaikan- perbaikan yang mereka sarankan (problem analysis).

4) Responden dapat diminta untuk merangking berbagai elemen (atribut) dari penawaran berdasarkan derajat pentingnyasetiap elemen dan seberapa baik kinerja perusahaan dalam

masing-masing elemen (importance/performance ratings).

\section{METODE PENELITIAN}

\section{A. Pendekatan Penelitian}

Pendekatan penelitian yang digunakan dalam penelitian ini adalah metode penelitian deskriptif dengan analisa kualitatif. Pendekatan penelitian ini menyajikan satu gambar yang terperinci tentang satu situasi khusus, setting sosial atau hubungan yang digunakan jika ada pengetahuan atau informasi tentang gejala sosial yang akan diselidiki atau dipermasalahkan. Pengetahuan tersebut diperoleh dari survei literatur, laporan hasil penelitian, atau dari hasil studi eksplorasi. Melalui pengetahuan atau informasi yang dimiliki tentang gejala yang diselidiki dan dengan melakukan pengukuran yang cermat atas masalah tersebut akan dapat dideskripsikan secara jelas dan terperinci. Penelitian ini disebut penelitian deskriptif karena peneliti menghasilkan data berupa gambaran dengan kalimat-kalimat mengenai kepuasan masyarakat terhadap pelayanan di Kantor Desa Tanggaran Kecamatan Pule Kabupaten Trenggalek.

\section{B. Fokus Penelitian}

Berdasarkan rumusan masalah yang telah dikemukakan, maka untuk memudahkan peneliti, maka dikemukakan fokus penelitian dalam penelitian ini sebagai berikut : 


\section{PUBLICIANA : JURNAL ILMU SOSIAL DAN ILMU POLITIK \\ VOLUME 14 NO 2 \\ ISSN : 1979 - 0295 / E-ISSN : $2502-7336$}

1. Tingkat kepuasan masyarakat terhadap pelayanan public di Kantor Desa Tanggaran Kecamatan Pule Kabupaten Trenggalek :
a. Persyaratan
b. Sistem, Mekanisme, dan Prosedur
c. Waktu Penyelesaian
d. Biaya/Tarif
e. Produk Spesifikasi Jenis Pelayanan
f. Kompetensi Pelaksana
g. Perilaku Pelaksana
h. Penanganan Pengaduan, Saran dan Masukan
i. Sarana dan Prasarana

2. Factor Pendukung dan penghambat dalam pelayanan public di Kantor Desa Tanggaran Kecamatan Pule Kabupaten Trenggalek

\section{Lokasi Penelitian}

Lokasi penelitian ini dilaksanakan di Desa Tanggaran Kecamatan Pule Kabupaten Trenggalek.

\section{Jenis dan Sumber Data}

Adapun jenis data yang penulis peroleh dalam penelitian lapangan ini adalah Data primer merupakan data dalam bentuk verbal atau kata-kata yang diucapkan secara lisan, gerak-gerik atau perilaku yang dilakukan oleh subjek yang dapat dipercaya, yakni subjek penelitian atau informan yang berkenaan dengan variabel yang diteliti atau data yang diperoleh dari responden secara langsung (Arikunto, 2010:22). Maka informan dalam penelitian ini adalah Kepala Desa, Perangkat Desa , dan beserta masyarakat Desa Tanggaran. Kepala Desa beserta Perangkat Desa dipilih sebagai informan selaku pemberi layanan. Dan dari masyarakat sebagai informan selaku pengguna layanan guna menemukan keselarasan antara pemberi layanan dan pengguna layanan. Data Sekunder, Data sekunder merupakan data yang diperoleh secara tidak langsung dari objek yang diteliti yang antara lain dilakukan melalui studi literatur, kepustakaan dan arsip/laporan

\section{E. Instrumen Penelitian}

Instrument utama dalam penelitian ini adalah peneliti itu sendiri. Adapun instrument pendukung yang digunakan untuk mengungkapkan data dalam penelitian ini adalah pedoman wawancara, pedoman observasi dan pedoman dokumentasi terstruktur yang dibuat sendiri oleh peneliti. Agar tidak terkesan kaku, peneliti berusaha menghafalkan terlebih dahulu isi pedoman wawancara, pedoman observasi dan pedoman dokumentasi agar penyampaiannya tidak tergesagesa.

\section{F. Teknik Pengumpulan Data}

Penelitian ini menggunakan sumber data yang diperoleh secara lisan dan tertulis. Teknik pengumpulan data yang digunakan dalam penelitian ini meliputi :

\section{Observasi}

Observasi yaitu teknik pengumpulan data dimana peneliti mencatat informasi sebagaimana mereka saksikan selama penelitian. teknik ini dilakukan dengan mengamati dan mencatat secara langsung di lokasi penelitian atas gejala-gejala yang ada kaitannya dengan objek yang diteliti, sehingga melalui proses ini penulis berusaha mendapatkan data yang dibutuhkan. Observasi dilakukan dengan tujuan untuk mengetahui secara langsung tentang keadaan Kantor Desa Tanggaran, lingkungan Kantor Desa Tanggaran, lingkungan Kantor Desa Tanggaran, 


\section{Slamet Hariyanto ${ }^{1}$, Heru Dwi Susilo²}

Evaluasi Kepuasan Masyarakat Terhadap Pelayanan Publik Di Kantor Desa Tanggaran Kecamatan Pule Kabupaten Trenggalek

fasilitas serta kegiatan pelayanan di Kantor Desa Tanggaran sehingga peneliti mendapatkan data yang akurat dengan tujuan penelitian yang diharapkan.

\section{Dokumentasi}

Dokumentasi digunakan untuk memperoleh informasi tentang keadaan Kantor Desa Tanggaran, seperti informasi mengenai visi misi, tugas pokok, fungsi dan struktur organisasi Kantor Desa Tanggaran serta informasi lainnya yang tercatat dalam bentuk lainnya yang berupa catatan, agenda, maupun landasan hokum. Dokumentasi digunakan untuk melengkapi data yang telah diperoleh melalui observasi dan kuesioner dengan cara meminta data kepada pihak-pihak yang teekait baik berupa arsip atau dokumen.

\section{Pengisian Kuesioner atau Angket Online}

Kuesioner atau angket merupakan teknik pengumpulan data yang dilakukan dengan cara memberi seperangkat pertanyaan atau pernyataan tertulis kepada responden untuk dijawabnya. Angket merupakan teknik pengumpulan data yang efisien apabila peneliti tahu pasti variable yang ingin diukur dan tahu apa yang bisa diharapkan dari responden.Pada penelitian ini, kuesioner atau angket digunakan untuk mengambil data tentang tingkat kepuasan masyarakat sebagai pelanggan dari pelayanan Kantor Desa Tanggaran.

\section{G. Teknik Analisa Data}

Teknik analisis data yang digunakan peneliti adalah teknik analisis data kualitatif dimana data yang diperoleh akan dianalisis dengan menggunakan teknik analisis data kualitatif. Metode penelitian kualitatif adalah suatu metode penelitian untuk menghasilkan data deskriptif berupa kata-kata tertulis maupun lisan dari data kuesioner. Teknik analisis data kualitatif digunakan untuk mendapatkan penjelasan mengenai bagaimana tingkat kepuasan masyarakat dalam pelayanan administrative di Kantor Desa Tanggaran Kecamatan Pule Kabupaten Trenggalek. Data dari hasil kuesioner yang diperoleh kemudian dicatat dan dikumpulkan sehingga menjadi sebuah catatan lapangan. Analisis data adalah proses penyederhanaan data dalam bentuk yang lebih mudah dibaca dan diinterpretasikan. Analisa data dalam penelitian kualitatif dilakukan mulai sejak awal sampai sepanjang proses penelitian berlangsung. Dalam penelitian kualitatif tidak ada panduan buku untuk melakukan analisis data, namun secara umum dalam analisis data selalu ada komponen-komponen yang wajib harus ada seperti pengambilan data, kategori data, dan kesimpulan.

\section{HASIL DAN PEMBAHASAN}

\section{Tingkat Kepuasan Masyarakat Terhadap Pelayanan Publik Di Kantor Desa Tanggaran Kecamatan Pule Kabupaten Trenggalek}

Penelitian ini bertujuan untuk mengetahui kepuasan masyarakat terhadap pelayanan public di kantor Desa Tanggaran KEcamatan Pule Kabupaten Trenggalek yang dihitung sesuai ketentuan dalam PERMENPAN No 14 tahun `2017 tentang Pedoman Penyusunan Survei Kepuasan Masyarakat Unit Penyelenggara Pelayanan Publik. Hasil penelitian menunjukkan bahwa pelayanan di Kantor Desa Tanggaran Kecamatan Pule KAbupaten Trenggalek berada pada tingkat yang baik. Hal ini ditunjukkan dengan nilai Survei Kepuasan Masyarakat (SKM) dari 9 (Sembilan) unsur sebesar 3,07154 dan dengan nilai Ingterval Konversi sebesar 76,79. Unsur yang memiliki nilai SKM tertinggi adalah unsur biaya/tarif dengan nilai interval sebesar 3,20 dengan nilai indeks perunsur 80. Sedangkan unsur pelayanan yang memiliki nilai terendah 


\section{PUBLICIANA : JURNAL ILMU SOSIAL DAN ILMU POLITIK \\ VOLUME 14 NO 2 \\ ISSN : 1979 - 0295 / E-ISSN : 2502 - 7336}

adalah unsur waktu penyelesaian dengan rata-rata perunsur sebesar 2,98 dan nilai indeks perunsur sebesar 74,61. Berdasarkan data penelitian yang telah dianalisis, maka pada bagian ini akan dibahas hasil penelitian yang meliputi masing-masing unsur Survei Kepuasan Masyarakat yaitu : (a) Persyaratan (b) sistem, mekanisme, dan prosedur (c) waktu penyelesaian (d) biaya/tarif (e) produk spesifikasi jenis pelayanan (f) kompetensi pelaksana (g) perilaku pelaksana (h) penanganan pengaduan, saran, masukan (i) sarana dan prasarana. Pembahasan lebih rinci dari masing-masing unsur adalah sebagai berikut :

a. Persyaratan

Persyaratan adalah syarat yang harus dipenuhi dalam pengurusan suatu jenis pelayanan, baik persyaratan teknis maupun administratif. Persyaratan dalam pelayanan public di Kantor Desa Tanggaran berdasarkan keterbukaan kemudahan teknis dan administratif sesuai atau tidaknya syarat yang dibutuhkan dengan pelayanan yang masyarakat inginkan. Hasil penelitian menunjukkan bahwa persyaratan dalam pelayanan public di Kantor Desa Tanggaran belum sesuai dengan jenis pelayanan yang diinginkan masyarakat. Hal tersebut dilihat dari nilai SKM (Survei Kepuasan Masyarakat) untuk unsur persyaratan sebesar 3,04615 dengan nilai konversi SKM sebesar 76,15. Berdasarkan hasil penelitian diatas menunjukkan bahwa persyaratan dalam pelayanan public di Kantor Desa Tanggaran berada pada tingkat kurang baik. Masyarakat belum sepenuhnya mengetahui secara rinci dan jelas mengenai persyaratan yang harus dipenuhi dalam pelayanan public di Kantor Desa Tanggaran. Sehingga perlu penyampaian informasi yang jelas terkait persyaratan yang harus dipenuhiserta perlu upaya untuk terus meningkatkan kemudahan persyaratan pelayanan di Kantor Desa Tanggaran.

b. Sistem, Mekanisme, dan Prosedur

Prosedur adalah tata cara pelayanan yang dibakukan bagi pemberi dan penerima pelayanan, termasuk pengaduan. Unsur sistem, mekanisme, dan prosedur berdasarkan keterbukaan mendapatkan informasi mengenai prosedur pelayanan dan kejelasan prosedur/tahapan alur dan kesederhanaan prosedur pelayanan atau tata cara pelayanan pelayanan di Kantor Desa Tanggaran. Hasil penelitian menunjukkan bahwa sistem, mekanisme dan prosedur pelayanan di Kantor Desa Tanggaran mudah untuk didapatkan. Hal tersebut dapat dilihat dari nilai SKM (Survei Kepuasan Masyarakat) untuk sistem, mekanisme dan prosedur pelayanan sebesar 3,1077 dengan nilai konversi IKM sebesar 77,70. Berdasarkan hasil penelitian tersebut menunjukkan bahwa sistem, mekanisme, dan prosedur pelayanan di Kantor Desa Tanggaran berada pada tingkat baik. Masyarakat mudah mendapatkan informasi mengenai prosedur atau tahapan alur pelayanan di Kantor Desa Tanggaran.

c. Waktu Penyelesaian

Waktu Penyelesaian adalah jangka waktu yang diperlukan untuk menyelesaikan seluruh proses pelayanan dari setiap jenis pelayanan. Unsur waktu penyelesaian dalam penelitian ini terdiri dari dua sub indikator yaitu ketepatan waktu petugas pelayanan dalam memberikan pelayanan dan ketepatan jadwal/waktu pelayanan petugas kepada masyarakat. Hasil penelitian menunjukkan bahwa waktu penyelesaian pelayanan di Kantor Desa Tanggaran adalah kurang baik. Hal tersebut dapat dilihat dari nilai SKM (Survei Kepuasan Masyarakat) waktu penyelesaian pelayanan sebesar 2,98462 dengan nilai konversi IKM sebesar 74,61. Berdasarkan hasil penelitian tersebut menunjukkan bahwa waktu penyelesaian di Kantor Desa Tanggaran berada pada tingkat kurang baik. Sehingga berdasarkan hal tersebut, pelayanan di Kantor Desa Tanggaran perlu upaya untuk mempercepat lagi waktu penyelesaian pelayanan untuk 


\section{Slamet Hariyanto ${ }^{1}$, Heru Dwi Susilo ${ }^{2}$}

Evaluasi Kepuasan Masyarakat Terhadap Pelayanan Publik Di Kantor Desa Tanggaran Kecamatan Pule Kabupaten Trenggalek

meningkatkan kepuasan masyarakat. Berdasarkan analisis hasil penelitian, factor yang mempengaruhi kecepatan waktu penyelesaian adalah factor SDM yaitu dari segi kualitas. Sebagian besar pegawai di Kantor Desa Tanggaran lulusan SMA sederajat sehingga kemampuannya terbatas sehingga perlu diberikan pelatihan untuk mengatasi hal tersebut.

d. Biaya/Tarif

Biaya/Tarif adalah ongkos yang dikenakan kepada penerima layanan dalam mengurus dan/atau memperoleh pelayanan dari penyelenggara yang besarnya ditetapkan berdasarkan kesepakatan antara penyelenggara dan masyarakat. Biaya/tarif dalam pelayanan public di Kantor Desa Tanggaran dijabarkan dalam 2 hal yaitu mengenai keterjangkauan dan kesesuaian biaya pelayanan bagi masyarakat. Hasil penelitian menunjukkan bahwa biaya/tarif pelayanan di Kantor Desa Tanggaran baik. Hal tersebut dapat dilihat dari nilai SKM (Survei Kepuasan Masyarakat) Biaya/tarif pelayanan sebesar 3,20 dengan nilai konversi SKM sebesar 80. Berdasarkan hasil penelitian tersebut menunjukkan bahwa biaya/tarif pelayanan di Kantor Desa Tanggaran berada pada tingkat baik. Pada umumnya pelayanan public di Kantor Desa Tanggaran tanpa pungutan biaya atau gratis.

e. Produk Spesifikasi Jenis Pelayanan

Produk spesifikasi jenis pelayanan adalah hasil pelayanan yang diberikan dan diterima sesuai dengan ketentuan yang telah ditetapkan. Produk pelayanan ini merupakan hasil dari setiap spesifikasi jenis pelayanan. Unsur produk spesifikasi layanan dalam penelitian ini terdiri dari dua hal yaitu kesesuaian antara pelayanan yang diterima dengan ketentuan yang berlaku dan kesesuaian antara pelayanan yang diterima/dirasakan dengan pelayanan yang diharapkan. Hasil penelitian menunjukkan bahwa produk spesifikasi jenis layanan di Kantor Desa Tanggaran baik. Hal tersebut dapat dilihat dari nilai SKM (Survei Kepuasan Masyarakat) Produk Spesifikasi Jenis Layanan mendapatkan pelayanan sebesar 3,09231 dengan nilai konversi SKM sebesar 77,30. Berdasarkan hasil penelitian tersebut, menunjukkan bahwa produk spesifikasi jenis pelayanan berada pada tingkat baik. Pelayanan public yang diberikan oleh Kantor Desa Tanggaran sudah sesuai dengan ketentuan yang berlaku.

\section{f. Kompetensi Pelaksana}

Kompetensi Pelaksana adalah kemampuan yang harus dimiliki oleh pelaksana meliputi pengetahuan, keahlian, keterampilan, dan pengalaman. Unsur Kompetensi pelaksana di Kantor Desa Tanggaran dijabarkan dalam 2 hal yaitu mengenai keahlian dan kemampuan petugas pelayanan dalam memberikan pelayanan kepada masyarakat. Hasil penelitian pada kompetensi pelaksana dalam pelayanan public di Kantor Desa Tanggaran sudah baik. Hal tersebut dilihat dari nilai SKM (Survei Kepuasan Masyarakat) kompetensi pelaksana pelayanan sebesar 3,09231 dengan nilai konversi SKM sebesar 77,30.

Berdasarkan hasil penelitian tersebut, kompetensi pelaksana berada pada tingkat Baik. Meskipun unsur kompetensi pelaksana sudah cukup memberikan kepuasan kepada masyarakat, namun berdasakan hasil analisa penelitian kompetensi pelaksana atau kemampuan pegawai masih kurang sehingga masih perlu upaya untuk meningkatkan kemampuan pegawai dalam memberikan pelayanan kepada masyarakat.

g. Perilaku Pelaksana

Perilaku Pelaksana adalah sikap petugas dalam memberikan pelayanan. Perilaku pelaksana dalam melayani masyarakat yang akan mendapatkan pelayanan di Kantor Desa Tanggaran dijabarkan dalam 5 hal yaitu kesopanan, keramahan, kemudahan, tanggung jawab dan 


\section{PUBLICIANA : JURNAL ILMU SOSIAL DAN ILMU POLITIK \\ VOLUME 14 NO 2 \\ ISSN : 1979 - 0295 / E-ISSN : $2502-7336$}

pelayanan yang tidak membeda-bedakan golongan atau status masyarakat. Hasil penelitian menunjukkan bahwa perilaku pelaksana di Kantor Desa Tanggaran sudah baik. Hal tersebut dapat dilihat dari nilai SKM (Survei Kepuasan Masyarakat) perilaku pelaksana pelayanan sebesar 3,18462 dengan nilai konversi IKM sebesar 79,61. Berdasarkan hasil penelitian tersebut, unsur perilaku pelaksana berada pada tingkat baik. Pada dasarnya seluruh pegawai di Kantor Desa Tanggaran sangat ramah dan mempunyai attitude yang sangat baik. Dengan demikian perlu dipertahankan atau bahkan lebih ditingkatkan lagi agar memberikan kenyamanan kepada pengguna pelayanan.

h. Penanganan Pengaduan, Saran dan Masukan

Penanganan pengaduan, saran dan masukan, adalah tata cara pelaksanaan penanganan pengaduan dan tindak lanjut. Unsur penanganan pengaduan, saran, dan masukan dijabarkan dalam empat hal yaitu yaitu ketersediaan fasilitas dalam pengajuan keluhan (kotak saran, komplain melalui telepon), kesungguhan petugas dalam merespon/menanggapi komplain, kecepatan petugas dalam merespon komplain dan tindakan petugas dalam menyikapi komplain. Hasil penelitian menunjukkan bahwa penanganan pengaduan saran dan masukan dalam pelayanan public di Kantor Desa Tanggaran sudah baik. Hal tersebut dapat dilihat dari nilai SKM (Survei Kepuasan Masyarakat) penanganan pengaduan saran dan masukan mendapatkan pelayanan sebesar 3,12308 dengan nilai konversi SKM sebesar 78,07. Berdasarkan hasil penelitian tersebut unsur penanganan pengaduan saran, masukan berada pada tingkat baik. Sudah disediakan kotak saran di Kantor Desa Tanggaran sehingga masyarakat dapat memberikan saran melalui kotak saran tersebut atau bisa langsung menghubungi petugas pelayanan.

i. Sarana dan Prasarana

Sarana adalah segala sesuatu yang dapat dipakai sebagai alat dalam mencapai maksud dan tujuan. Prasarana adalah segala sesuatu yang merupakan penunjang utama terselenggaranya suatu proses (usaha, pembangunan, proyek). Sarana digunakan untuk benda yang bergerak (komputer, mesin) dan prasarana untuk benda yang tidak bergerak (gedung). Unsur Sarana dan prasarana di bagi menjadi 2 hal, yaitu ketersediaan kapasitas pelayanan, kenyamanan dan keamanan. Hasil penelitian menunjukkan bahwa sarana dan prasarana di Kantor Desa Tanggaran sudah baik. Hal tersebut dapat dilihat dari nilai SKM (Survei Kepuasan Masyarakat) sarana dan prasarana pelayanan sebesar 3,09231 dengan nilai konversi IKM sebesar 77,30. Berdasarkan hasil penelitian tersebut unsur sarana dan prasarana berda pada tingkat baik. Oleh karena itu pengelolaan, penataan, kerapian dan kebersihan harus dipertahankan dan ditingkatkan lagi untuk memberikan kenyamanan bagi pengguna pelayanan.

2. Faktor Penghambat dan Pendukung Terwujusnya Kualitas Pelayanan Publik Yang Baik Di Kantor Desa Tanggaran Kecamatan Pule Kabupaten Trenggalek

a. Factor Pendukung

1) Sumber Daya Manusia

Sumber Daya Manusi merupakan factor utama dalam pelaksanaan pelayanan public. Sikap pegawai dalam memberikan pelayanan mempengaruhi kenyamanan masyarakat sebagai pengguna pelayanan. Sikap seseorang dipengaruhi oleh factor dari dalam diri pegawai itu sendiri dan faktor lingkungan. Faktor dari dalam dapat berupa karakter dari pegawai tersebut, keadaan kejiwaan yang sedang terjadi dalam diri pegawai tersebut, dan faktor-faktor lainnya. Sedangkan factor dari luar yang berupa lingkungan kerja dapat berasal dari teman kerja, juga dari masyarakat yang mencari pelayanan. Karakter orang yang memang dalam kesehariannya ramah dan murah 


\section{Slamet Hariyanto ${ }^{1}$, Heru Dwi Susilo ${ }^{2}$}

Evaluasi Kepuasan Masyarakat Terhadap Pelayanan Publik Di Kantor Desa Tanggaran Kecamatan Pule Kabupaten Trenggalek

senyum, maka akan berpengaruh terhadap sikapnya ketika berhadapan dengan masyarakat yang mencari layanan. Ramah, murah senyum, dan penuh canda akan menjadikan pegawai tersebut dapat melaksanakan tugasnya dengan baik dan membuat masyarakat puas. Sikap melayani harus ditumbuhkan dalam diri pegawai yang merupakan abdi negara dan abdi masyarakat. Berdasarkan hasil penelitian, factor pendukung sumber daya manusia dijabarkan ke dalam 2 (dua) hal yaitu sikap pegawai dan kesadaran pegawai. Sikap pegawai dalam memberikan pelayanan di Kantor Desa Tanggaran ramah, murah senyum, dan penuh canda namun tetap tidak mengurangi profesionalitas dalam pekerjaan. Sedangkan kesadaran pegawai/aparatur dalam memberikan pelayanan di Kantor Desa Tanggaran sudah berdasarkan tugas pokok dan fungsi standar operasional penyelenggaraan pelayanan public.

\section{2) Sarana dan Prasarana}

Faktor sarana dan prasarana yang dimaksud disini ialah segala jenis peralatan, perlengkapan kerja dan fasilitas lainnya yang berfungsi sebagai alat utama dalam pelaksanaan pekerjaan, dan juga berfungsi sebagai alat utama dalam pelaksanaan pekerjaan, dan juga berfungsi dalam rangka kepentingan orang-orang yang sedang berhubungan dengan organisasi. Hasil penelitian menunjukkan bahwa sarana dan prasarana di Kantor Desa Tanggaran sudah baik. Seperti computer dan printer yang masih dalam kondisi layak digunakan, meja dan kursi pelayanan yang tertata rapi serta ruang tunggu pelayanan yang memadai. Sehingga hal demikian dapat memberikan kenyamanan kepada masyarakat sebagai penerima pelayanan.

3) Respon Masyarakat

Selain factor internal, factor pendukung pelayanan public di Kantor Desa Tanggaran juga terdapat factor eksternal yaitu respon mayarakat terhadap pelayanan yang diberikan oleh pegawai/aparat. Respon yang positif tentunya akan menjadi pendukung bagi pelayanan kepada masyarakat. Sebaliknya respon yang negative tentu menjadi penghambat pelayanan yang diberikan oleh pegawai Kantor Desa Tanggaran kepada masyarakat. Hasil penelitian menunjukkan bahwa masyarakat Desa Tanggaran memberikan respon positif terhadap pelayanan yang diberikan pegawai/aparat di Kantor Desa Tanggaran. Respon positif yang diberikan seperti mantaati segala peraturan yang ada di Kantor Desa Tanggaran, beretika baik kepada petugas pelayanan, serta menghargai petugas pelayanan meskipun terdapat kekurangan.

b. Factor Penghambat

1) Sumber Daya Manusia

Kualitas sumber daya manusia merupakan factor yang penting dalam pelayanan public di Kantor Desa Tanggaran. Karena kemampuan dan ketrampilannya dalam memberikan pelayanan public mempengaruhi kepuasan masyarakat. Hasil penelitian menunjukkan bahwa kualitas sumber daya manusia di Kantor Desa Tanggaran pada kondisi yang masih rendah. Rata-rata aparatur di Kantor Desa Tanggaran lulusan SMA sederajat, hanya terdapat beberapa saja yang berpendidikan S1. Sehingga ketrampilan dalam penggunaan computer utamanya terbatas.

2) Komunikasi

Komunikasi merupakan proses penyampaian informasi dari satu orang kepada orang lain, baik langsung maupun tidak langsung, secara tertulis maupun lisan. Dengan demikian komunikasi merupakan factor penting dalam pelayanan public di Kantor Desa Tanggaran. Dengan informasi masyarakat sebagai pengguna layanan mudah mengetahui dan memahami prosedur dalam pelayanan public di Kantor Desa Tanggaran. Berdasarkan hasil penelitian, di Kantor Desa Tanggaran masih belum tersedia papan informasi sehingga penyampaian informasi mengenai 


\section{PUBLICIANA : JURNAL ILMU SOSIAL DAN ILMU POLITIK \\ VOLUME 14 NO 2 \\ ISSN : 1979 - 0295 / E-ISSN : 2502 - 7336}

persyaratan dan prosedur pelayanan masih belum jelas. Hal tersebut membuat masyarakat sebagai pengguna layanan harus bolak balik untuk menanyakan persyaratan serta melengkapi persyaratan tersebut, sehingga masyarakat menganggap pelayanan public di Kantor Desa Tanggaran berbelit-belit.

3) Kepastian Jadwal Pelayanan

Kepastian jadwal pelayanan Kantor Desa Tanggaran dijabarkan dalam pernyataan mengenai kesesuaian waktu pelayanan dengan jadwal pelayanan yang telah ditentukan. Hasil penelitian menunjukkan kepastian jadwal pelayanan di Kantor Desa Tanggaran belum sesuai dengan jadwal pelayanan. Hal tersebut dikarenakan banyak aparat yang tidak disiplin dalam mematuhi waktu kerja. Sehingga jadwal pelayanan yang diberikan terlambat dari jadwal pelayanan yang telah ditentukan.

\section{KESIMPULAN DAN SARAN}

\section{A. Kesimpulan}

Berdasarkan hasil penelitian yang telah diuraikan sebelumnya dapat disimpulkan sebagai berikut

Tingkat kepuasan masyarakat terhadap pelayanan public di Kantor Desa Tanggaran Kecamatan Trenggalek. Berdasarkan perhitungan Survei Kepuasan Masyarakat yang mengacu pada PERMENPAN No 14 tahun 2017 tentang Pedoman Penyusunan Survei Kepuasan Masyarakat Unit Penyelenggara Pelayanan Publik. Maka diperoleh nilai Survei Kepuasan Masyarakat (SKM) dari 9 (Sembilan) unsur sebesar 3,07154 dan dengan nilai Interval Konversi sebesar 76,79. Sehingga kualitas pelayanan public berada pada tingkat "B". Hal ini menunjukkan bahwa kinerja pelayanan public di Kantor Desa Tanggaran Kecamatan Pule Kabupaten Trenggalek secara keseluruhan termasuk dalam kategori baik. Berdasarkan 9 (Sembilan) unsur pelayanan yang diteliti, biaya/tarif merupakan unsur dengan nilai indeks tertinggi dengan nilai SKM sebesar 80 dan berada pada tingkat baik. Sedangkan unsur dengan nilai indeks terendah yaitu unsur waktu penyelesaian dengan nilai SKM sebesar 74,61 dan berada pada tingkat kurang baik. Hasil Survei Kepuasan Masyarakat masing-masing unsur antara lain : Persyaratan dalam pelayanan public di Kantor Desa Tanggaran memiliki nilai SKM sebesar 76,15 dan berada pada tingkat kurang baik. Sistem, mekanisme, prosedur dalam pelayanan public di Kantor Desa Tanggaran memiliki nilai SKM sebesar 77,70 dan berada pada tingkat baik. Waktu penyelesaian dalam pelayanan public di Kantor Desa Tanggaran memiliki nilai SKM sebesar 74,61 dan berada pada tingkat kurang baik. Biaya/Tarif dalam pelayanan public di Kantor Desa Tanggaran memiliki nilai SKM sebesar 80 dan berda pada tingkat baik. Produk spesifikasi jenis pelayanan dalam pelayanan public di Kantor Desa Tanggaran memiliki nilai SKM sebesar 77,30 dan berada pada tingkat baik. Kompetensi pelaksana dalam pelayanan public di Kantor Desa Tanggaran memiliki nilai SKM sebesar 77,30 dan berada pada tingkat baik. Perilaku pelaksana dalam pelayanan public di Kantor Desa Tanggaran memiliki nilai SKM sebesar 79,61 dan berada pada tingkat baik. Penanganan pengaduan, saran dan masukan dalam pelayanan public di Kantor Desa Tanggaran memiliki nilai SKM sebesar 78,07 dan berda pada tingkat baik. Sarana dan prasarana dalam pelayanan public di Kantor Desa Tanggaran memiliki nilai SKM sebesar 77,70 dan berda pada tingkat baik.

Faktor pendukung dan penghambat dalam pelayanan public di Kantor Desa Tanggaran Kecamatan Pule Kabupaten Trenggalek. 


\section{Slamet Hariyanto ${ }^{1}$, Heru Dwi Susilo ${ }^{2}$}

Evaluasi Kepuasan Masyarakat Terhadap Pelayanan Publik Di Kantor Desa Tanggaran Kecamatan Pule Kabupaten Trenggalek

\section{a. Factor Pendukung}

Sumber Daya Manusia. Sikap pegawai yang ramah, murah senyum, penuh canda serta kesadaran pegawai dalam memberikan pelayanan berdasarkan standar operasional pelayanan public telah memberikan kepuasan kepada masyarakat sebagai pengguna pelayanan.

Sarana dan Prasarana. Factor sarana dan prasarana di Kantor Desa Tanggaran cukup memadai sehingga memberikan kenyamanan kepada masyarakat sebagai pengguna pelayanan.

Respon Masyarakat. Masyarakat Desa Tanggaran memberikan respon yang positif terhadap pelayanan yang diberikan pegawai/aparat sehingga petugas pemberi pelayanan merasa dihargai.

b. Factor Penghambat

Sumber Daya Manusia. Kualitas Sumber Daya Manusia di Kantor Desa Tanggaran masih rendah. Rata-rata aparatur di Kantor Desa Tanggaran lulusan SMA Sederajat, sehingga ketrampilannya masih terbatas.

Komunikasi. Kantor Desa Tanggaran belum menyediakan papan informasi sebagai media penyampaian informasi yang tertulis sehingga informasi mengenai persyaratan dan prosedur pelayanan belum jelas.

Kepastian Jadwal Pelayanan. Jadwal pelayanan di Kantor Desa Tanggaran belum sesuai dengan jadwal pelayanan yang telah ditentukan.

\section{B. Saran}

Berdasarkan kesimpulan penelitian diatas, maka peneliti memberikan saran kepada Kantor Desa Tanggaran Kecamatan Pule Kabupaten Trenggalek, yaitu sebagai berikut : Kantor Desa Tanggaran perlu menambah ketrampilan para pegawai/aparatur agar dapat meningkatkan kepuasan masyarakat. Misalnya dengan mengirimkan pegawainya mengikuti pelatihan atau mengadakan pelatihan internal khusus pegawai/aparatur pemerintahan Desa Tanggaran.

Kantor Desa Tanggaran seharusnya dapat memberikan informasi yang jelas kepada masyarakat terkait persyaratan pelayanan agar masyarakat tidak menganggap persyaratan pelayanan public terlalu berbelit. Contohnya dengan memberikan papan informasi mengenai prosedur, persyaratan, biaya, dan waktu pelayanan pada setiap jenis pelayanan yang dapat dilihat langsung oleh masyarakat.

Kantor Desa Tanggaran seharusnya memberikan Reward and Punishment kepada pegawai/aparat Di Kantor Desa Tanggaran. Hal ini dimaksudkan agar pegawai dapat bekerja dengan maksimal serta dengan adanya punishment agar mereka dapat disiplin mematuhi waktu kerja.

\section{DAFTAR PUSTAKA}

Depdagri-LAN, 2007. Modul Kebijakan Pelayanan Publik, Diklat Teknis Pelayanan Publik, Akuntabilitas dan Pengelolaan Mutu (Public Service Delivery, Accountability, and Quality Management). Jakarta:LAN.

Fandy, Tjiptono, 2000, Manajemen jasa, Edisi Kedua And Offsek, Yogyakarta.

Hanif, Nurcholis. 2007. Teori dan Praktik Pemerintahan dan Otonomi Daerah. Jakarta: Grasindo Hardiyansyah, Hardiyansyah. 2018. Kualitas Pelayanan Publik: Konsep, Dimensi, Indikator dan Implementasinya. Yogyakarta: Gava Media.

Ibrahim, Amin. 2008. Teori dan Konsep Pelayanan Publik serta Implementasinya. Bandung: Mandar Maju. 


\section{PUBLICIANA : JURNAL ILMU SOSIAL DAN ILMU POLITIK \\ VOLUME 14 NO 2 \\ ISSN : 1979 - 0295 / E-ISSN : $2502-7336$}

Lovelock, Christoper H. 1991. Service Marketing. USA: Prentice Hall, Inc.

Mahmudi, 2005. Manajemen Kinerja Sektor Publik. Yogyakarta: UPP STIM YKPN.

Nasution, M.N. 2005. Manajemen Mutu Terpadu: Total Quality Management.

Bogor: PT. Ghalia Indonesia.

Ratminto \& AtikSeptiWinarsih.2007. Manajemen Pelayanan. Yogyakarta: Pustak Pelajar.

Supranto. 1997. Mengukur Tingkat Kepuasan Pelanggan. Jakarta: Rineka Cipta. Tjiptono, Fandy. 1995. Manajemen Jasa. Yogyakarta: Andi.

Zeithaml, Valarie A., A. Parasuraman \& Leonard L. Berry. 1990. Delivering Quality Service. New York: The Free Press

Instruksi Presiden Nomor 1 Tahun 1995 tentang Perbaikan dan Peningkatan Mutu Pelayanan.

Keputusan Menteri Negara Pemberdayaan Aparatur Negara Nomor 63/KEP/M.PAN/7/2003 Tentang Pedoman Umum Penyelenggaraan Pelayanan Publik.

Keputusan Menteri Pendayagunaan Aparatur Negara Nomor 25 Tahun 2004 tentang Pedoman Penyusunan Indeks Kepuasan Masyarakat Unit Pelayanan Instansi Pemerintah.

PERMENPAN Nomor 14 Tahun 2017 Tentang pedoman penyusunan survei Kepuasan Masyarakat Unit Penyelenggara Pelayanan Public Undang-Undang Nomor 25 Tahun 2009 Tentang Pelayanan Publik.

http://Kamusbahasaindonesia.Org/Pelayanan, diakses pada tanggal 02 April 2021 